\title{
Assessment of chest X-ray images in newborns with respiratory disorders
}

\author{
Łukasz Maciej Czarnecki \\ Department of Diagnostic Imaging, SPSK1, Zabrze, Poland \\ Kardiochirurgia i Torakochirurgia Polska 2015; 12 (1): 83-86
}

\begin{abstract}
The aim of the study was to analyze major radiological signs on chest X-ray images of neonates with respiratory disorders. The analyzed group consisted of 84 neonates; 56 were born prematurely. In total, 386 X-ray photographs of the neonates were taken; of these, 301 were chest radiographs. The following conditions were diagnosed: pneumonia $(n=44)$, infant respiratory distress syndrome $(n=28)$, bronchopulmonary dysplasia $(n=9)$, atelectasis $(n=5)$, and meconium aspiration syndrome $(n=3)$. The initial X-ray images of 29 neonates were normal. Reduced aeration of lung tissue was diagnosed in 55 patients, increased lung tissue aeration in 6. A pathologically widened mediastinal shadow was observed in 4 newborns; in 4 cases, evaluation was not possible. The final radiographs were normal in 41 cases. The most common radiological sign in respiratory disorders is the reduction of lung aeration. Chest $X$-ray examination plays a significant role in the diagnostics of respiratory disorders, which may be caused be factors unrelated to the respiratory system.

Key words: neonate, respiratory disorder, chest X-ray.
\end{abstract}

\section{Streszczenie}

Celem pracy była analiza głównych objawów radiologicznych widocznych na zdjęciach klatki piersiowej noworodków z zaburzeniami układu oddechowego. Badana grupa składała się z 84 noworodków, z których 56 było przedwcześnie urodzonych. Wszyscy pacjenci mieli w sumie wykonanych 386 zdjęć rentgenowskich, z czego 301 stanowiły zdjęcia klatki piersiowej. Zdiagnozowano: zapalenie płuc u 44, zespół zaburzeń oddechowych u 28, dysplazję oskrzelowo-płucną u 9, niedodmę u 5, zespół aspiracji smółki u 3 noworodków. Prawidłowy obraz radiologiczny stwierdzono u 29 noworodków w pierwszym badaniu. Zmniejszenie powietrzności płuc rozpoznano u 55, zwiększenie powietrzności płuc u 6 chorych. Patologicznie poszerzony cień śródpiersia zaobserwowano u 4 noworodków, w 4 przypadkach ocena była niemożliwa. Ostatnie zdjęcia rentgenowskie były prawidłowe u 41 noworodków. Najczęstszym objawem radiologicznym w zaburzeniach układu oddechowego jest spadek powietrzności płuc. Rentgenogram klatki piersiowej w przypadku zaburzeń oddechowych odgrywa znaczącą rolę. Zaburzenia oddychania mogą mieć przyczyny inne niż jedynie te związane z układem oddechowym.

Słowa kluczowe: zaburzenia oddychania, noworodki, RTG klatki piersiowej.

tension, or circulatory system disorders; they may also be acquired after birth, e.g. infant respiratory distress syndrome (IRDS), bronchopleural dysplasia (BPD) [1], pneumothorax, transient tachypnea of the newborn (TTN), meconium aspiration syndrome (MAS), hypovolemia, metabolic disorders, pneumonitis [2], or cerebral causes. Due to the large number of possible culprits, chest X-ray examination is recommended in the case of any newborn who is suffering from respiratory disorders [1, 2].

Chest X-ray is the primary examination for children with respiratory disorders of various etiology. It should be mentioned that it is one of the first examinations performed in newborns admitted to intensive care units; additional ex- 
aminations are often performed if the patient's clinical condition deteriorates for reasons believed by the clinicians to be related to the respiratory system [16].

The decided majority of chest X-ray images are taken with the newborn lying down; less frequently, the photograph is taken using a special harness that keeps the newborn in a vertical position. In the case of children in a very severe condition, the $\mathrm{X}$-ray images are taken by the patient's bed; modern incubators are adapted for this and have special drawers for the X-ray cassette [11]. The photographs are taken in anteroposterior projection, without the use of an anti-scattering grid, often with hard radiation.

The aim of the study was to assess radiological signs present on the chest X-ray photographs of neonates with respiratory disorders.

\section{Material and methods}

The study group consisted of 84 neonates who underwent chest X-ray examination at the Institute of Radiology of the Medical University of Silesia in Zabrze between January 1, 2010 and April 30, 2010. The children were hospitalized at the ICU and the Neonatal Pathology Department of the Chair of Pediatrics in Zabrze.

The group included 49 boys (59.4\%) and 35 girls (40.6\%). Fifty-six children (67.2\%) were born prematurely; 22 of these premature infants (39.5\%) were born after less than 30 weeks of gestation (extreme prematurity). In total, 386 X-ray photographs of the neonates were taken; of these, 301 were chest $X$-ray images $(77.8 \%)$, while the remaining photographs came from plain abdominal $X$-ray examinations and intestinal transit studies. All the radiographs were evaluated, and the observed pathologies were summarized.

\section{Results}

In the studied group of children, the chest X-ray image of the lungs was normal in 29 neonates (34.4\%). In 13 cases in which the first lung image was normal, a pathology was revealed on the second photograph; in 9 cases, the pathology was described after taking at least $3 \mathrm{X}$-ray images. The most frequent pathology found on the follow-up images taken among neonates with a normal chest image on the first photograph was pneumonitis $(n=9)$, followed by infant respiratory distress syndrome (IRDS) $(n=5)$; in the remaining cases, the images showed no abnormalities, or the first photograph was the only one taken $(n=8)$.

The final chest photograph showed no abnormalities in 44 neonates (48.8\%).

The radiological signs observed in the study group during hospitalization included: reduced aeration of lung tissue $(n=55)$, increased lung tissue aeration $(n=9)$, atelectasis $(n=5)$, edematous changes $(n=3)$, pneumothorax $(n=2)$, pathological widening of the mediastinal shadow $(n=4)$; in 4 cases, concomitant pathologies of the lung tissue precluded evaluation. Increased pulmonary blood flow was noted in 4 newborns; in 1 case, the cardiac silhouette was impossible to evaluate, while in the remaining 3 cases, the size of the heart was normal. In 1 patient, reduced pulmonary flow was observed along with concomitant enlargement of the cardiac silhouette (cardiothoracic ratio > 0.7).

Among the patients in whom the chest radiographs indicated reduced lung tissue aeration, the most frequent nosological entity was pneumonitis, as diagnosed in 44 neonates (Fig. 1). In some of these patients, pneumonitis was accompanied by another pathology associated with a reduction of lung aeration.

Based on the referral records, congenital pneumonitis was suspected in 17 neonates. It was confirmed in 12 patients in whom the changes were already visible on the first radiograph; in 5 patients, inflammatory changes were diagnosed without a previous suspicion of pneumonitis. Among the patients with congenital inflammatory changes visible on the first radiograph, unilateral right-sided lesions were revealed in 6 neonates, bilateral lesions were found in 10 neonates, and left-sided inflammation was discovered

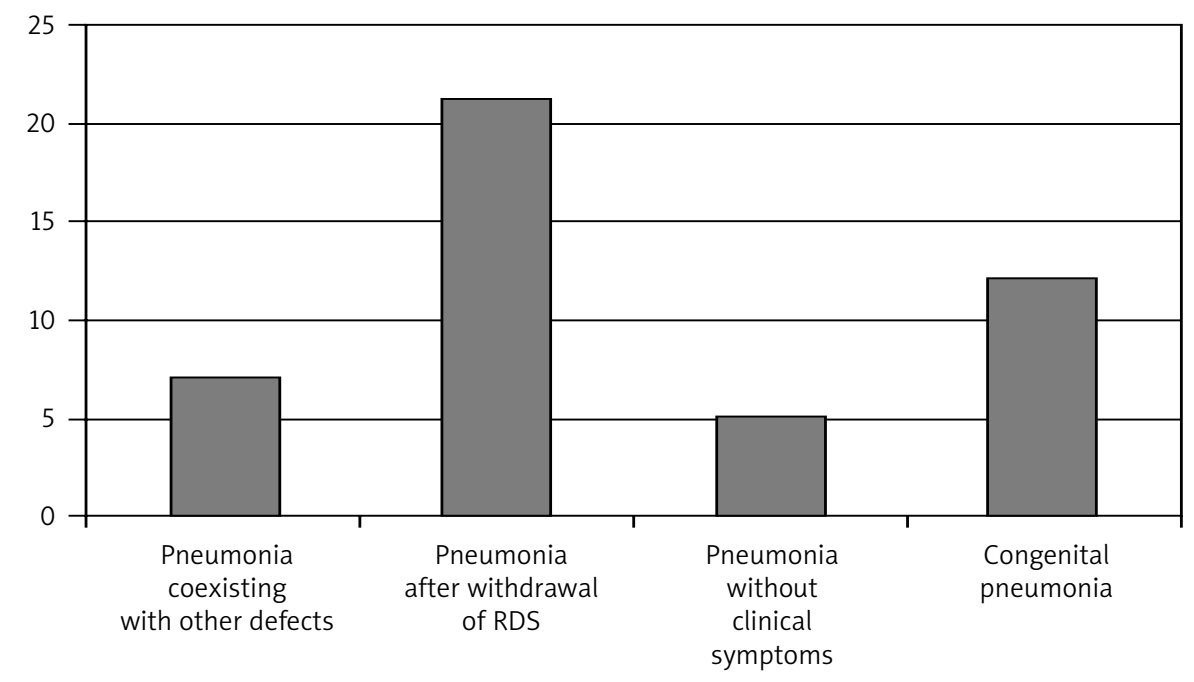

Fig. 1. Division of patients diagnosed with pneumonitis based on X-ray imaging 


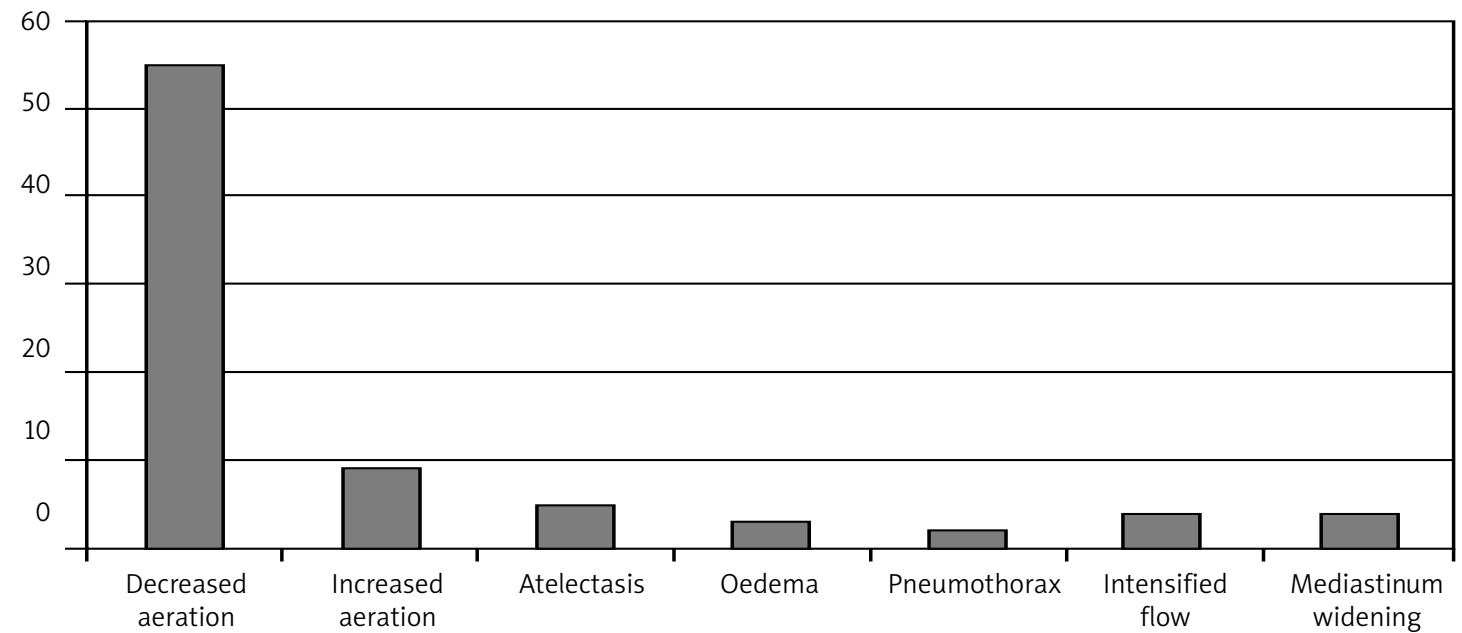

Fig. 2. Quantitative division of the major radiological signs in the studied group of neonates

in 1 neonate. In the remaining 27 patients, pneumonitis was diagnosed during the hospitalization, in 21 cases after the abatement of IRDS and in 7 with other concomitant pathologies. In total, bilateral massive inflammation occurred in 21 neonates, right-sided perihilar changes in 6, and bilateral perihilar changes in 3 . Signs of lobar right-sided pneumonitis were present in 12 neonates; in 9 cases, the lower lobe of the right lung was involved, in 2 the middle lobe, and in 1 the upper lobe. The images of two neonates indicated massive left-sided pneumonitis. In the case of 1 neonate, the radiograph indicated changes involving the upper lobe of the left lung and the middle lobe of the right lung.

Infant respiratory distress syndrome was diagnosed in 28 neonates (Fig. 2); in 9 cases, the diagnosis was made after the first radiograph, while in the remaining 19 cases, it was made after more chest X-ray photographs were taken. $1^{\text {st }}$-degree IRDS was diagnosed in 17 neonates, $2^{\text {nd }}$-degree in $9,3^{\text {rd }}$-degree in 1 , and $4^{\text {th }}$-degree in 1 neonate. Changes consistent with IRDS were only visible on the first radiographs in the case of 13 neonates; they persisted on $>1$ radiograph in another 15 cases.

Bronchopulmonary dysplasia (BPD) was observed in 9 neonates, including 4 neonates suffering from high-degree dysplasia. In 8 neonates, dysplasia occurred after IRDS, and in 1 after the abatement of pulmonary inflammation.

Meconium aspiration syndrome (MAS) was clinically suspected and radiologically confirmed in 3 neonates.

The most commonly observed radiological sign in the studied neonates suffering from respiratory disorders was reduced lung tissue aeration. The most frequent diagnosis among the patients with this sign was pneumonitis, followed by IRDS.

On the majority of the chest radiographs, more than one pathology was diagnosed, and the nosological entity was often subject to change.

Since most of the neonates were mechanically ventilated during the hospitalization, interstitial emphysema was frequently diagnosed; it was concomitant with pneumonitis, IRDS, pneumothorax, and other nosological entities.
It is also noteworthy that, in a significant portion of the studied patients, no lung pathologies were found by the radiological examinations in spite of the clinical diagnosis of respiratory disorders. It may, therefore, be surmised that respiratory disorders can also be caused by factors unrelated to the respiratory system. In 8 of the patients with normal results of their first chest radiographs, this was the only photograph taken; from this group, 3 patients died before a follow-up photograph could be obtained.

According to the analysis of the chest radiographs, the observed pathology most often involved the tissue of both lungs. None of the examinations revealed a pathology limited to the right lung, and no isolated pathological lesions in the left lung were visualized.

\section{Discussion}

X-ray examination of the chest plays a significant role in the diagnostics of respiratory disorders in children [5, $12,16]$. It is an essential tool in the diagnostics of both congenital $[1,13]$ and acquired defects $[2,13]$. The clinical symptoms occurring in neonates with respiratory disorders are often non-specific; therefore, chest X-ray photographs allow clinicians to revise the diagnosis [1, 2]. Clinical symptoms and radiological signs are not always consistent. Among the neonates with respiratory disorders examined at our center, the first chest X-ray photograph was normal in $34.4 \%$ of cases; the rate reported by other centers was lower and averaged to 31\% [14].

Out of the 99 neonates with signs of respiratory disorders examined at the Department of Neonatology of the Children's Hospital in Kuopio, Finland, 66 children exhibited radiological signs that were correlated with the clinical symptoms; the highest consistency was demonstrated in the case of IRDS diagnostics, the lowest in the case of children with transient tachypnea of the newborn (TTN) (48\%). The authors concluded that, in many cases lacking radiological confirmation, the first $\mathrm{X}$-ray image was taken prematurely. 
In neonatal intensive care units, X-ray imaging is one of the earliest [5] and most frequently performed diagnostic examinations [7, 11]; therefore, numerous authors underscore the necessity of reducing the number of X-ray photographs taken in neonates $[7,8]$. Chest X-ray examinations constituted $77.8 \%$ of all radiological examinations conducted at our center, which does not differ significantly from the results of other centers reporting this percentage at approximately $70 \%$ [7]. Balancing the dose of ionizing radiation is one of the priorities of modern imaging diagnostics $[5,6,8]$; many authors highlight the role of radiation in increasing the risk of tumors later in childhood $[9,10]$.

Conducting imaging diagnostics in neonates has unique characteristics; therefore, performing imaging examinations in such patients must accommodate their needs [5, $7,11]$.

\section{Conclusions}

In the presence of respiratory disorders, chest X-ray examination plays a significant role in neonatal diagnostics.

The most frequently observed radiological symptom in the studied neonates with respiratory disorders was pneumonitis.

According to the analysis of the chest radiographs obtained from the study group, the pathology most often involved the tissue of both lungs.

Respiratory disorders may have causes other than those related to the respiratory system.

\section{References}

1. Wilson AC. What does imaging the chest tell us about bronchopulmonary dysplasia? Paediatr Respir Rev 2010; 11: 158-161.
2. Restrepo R, Palani R, Matapathi UM, Wu YY. Imaging of round pneumonia and mimics in children. Pediatr Radiol 2010; 40: 1931-1940.

3. Vaucher YE. Bronchopulmonary dysplasia: an enduring challenge. Pediatr Rev 2002; 23: 349-358.

4. Baraldi E, Filippone M. Chronic lung disease after premature bright. N Engl J Med 2007; 357: 1946-1955.

5. Kellenberger CJ. Imaging children - what is special? Ther Umsch 2009; 66: 55-59.

6. Carlander A, Hansson J, Söderberg J, Steneryd K, Båth M. Clinical evaluation of a dual-side readout technique computed radiography system in chest radiography of premature neonates. Acta Radiol 2008; 49: 468-474.

7. Bader D, Datz H, Bartal G, Juster AA, Marks K, Smolkin T, Zangen S, Kugelman A, Hoffmann C, Shani G, Ben-Shlomo A, Margaliot M, Sadetzki S. Unintentional exposure of neonates to conventional radiography in the Neonatal Intensive Care Units. J Perinatal 2007; 27: 579-585.

8. Van den Boom J, Battin M. Chest radiographs after removal of chest drains in neonates: clinical benefit or common practice? Arch Dis Child Fetal Neonatal Ed 2007; 92: F46-48.

9. Wilson-Costello D, Rao PS, Morrison S, Hack M. Radiation exposure from diagnostic radiographs in extremely low birth weight infants. Pediatrics 1996; 97: 369-374.

10. Armpilia Cl, Fife IA, Croasdale PL. Radiation dose quantities and risk in neonates in a special care baby unit. Br J Radiol 2002; 75: 590-595.

11. Slade D, Harrison S, Morris S, Alfaham M, Davis P, Guildea Z, Tuthill D. Neonates do not need to be handled for radiographs. Pediatr Radiol 2005; 35: 608-611.

12. Arthur R. The neonatal chest X-ray. Paediatr Respir Rev 2001; 2: 311-323.

13. Roggini M, Pepino D, D’Avanzo M, Andreoli GM, Ceccanti S, Capocaccia P. Respiratory distress in newborn: evaluation of chest X-rays. Minerva Pediatr 2010; 62 (3 Suppl 1): 217-219.

14. Koskas M, Chadelat K, Chevalier JY, Cottin JF, Osika E, Clément A, Tournier G, Costil J, Boulé M. Clinical and respiratory function follow-up of 39 infants treated with neonatal respiratory extracorporeal assistance. Arch Pediatr 1999; 6: 263-270.

15. Kurl S, Heinonen KM, Kiekara O. The first chest radiograph in neonates exhibiting respiratory distress at birth. Clin Pediatr (Phila) 1997; 36: 285-289.

16. Sraga W, Głowacki J, Kluczewska E, Myga-Porosiło J, Legaszewski T, Czarnecki $Ł$, Król K, Kozioł $Ł$. Comparative analysis of imaging examinations of the thoracic cage in neonates. Defining indications for cat scanning. Kardiochir Torakochir Pol 2013; 10: 295-298. 